\title{
Baby Boomers And Generation X Industrial Salespeople: Generational Divide Or Convergence?
}

Sue DelVecchio, East Carolina University, USA

\begin{abstract}
Currently two of the largest generational groups occupying industrial field sales positions are Generation X and Baby Boomers. While anecdotal evidence suggests these two generations are widely different, few studies have compared their career attitudes. Working within the conceptual framework of psychological employment contracts this study tested the notion that Generation X would be more transactional and Baby Boomers would be more relational in nature. This nature was expected to take the form of higher intrinsic motivation levels and fewer career path changes among Baby Boomers. While Baby Boomers do tend to express higher levels of intrinsic motivation, their career paths are less relational than expected (i.e. their careers are spanning more than one employer). Overall the findings provide partial support for some of the relational theory expectations- and more importantly dispel still others. Managers faced with intergenerational field sales forces may similarly, therefore, question the assumption that Baby Boomer field salespeople will follow the relational employment contract profile.
\end{abstract}

Keywords: Generational comparisons or age cohorts, field sales personnel, career, path, work-related behaviors.

\section{INTRODUCTION}

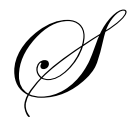

ocial scientists have found the Baby Boomers and Generation Xers consistently emerge as two distinct groups -each with their own separate set of shared collective memories (Arsenault 2004; Schuman and Scott 1989). Historically, generational researchers claim the values of each group are a response to the separate shared collective memories (Mannheim 1953). For example, Baby Boomers place a higher value on independence and rebellion than other generational groups studied by Mitchell (1995). Sociologists claim this emphasis on independence was a result of being raised under tight adult protection by parents who experienced the Great Depression and a World War. Generation Xers', on the other hand, were raised during a time of doubling divorce rates and fewer childcare options which led to less immediate and direct adult protection. Generation X'ers, express higher levels of skepticism and less security (Glass 2007). Since major events define generations, those events should be reflected in the work attitudes and career choices of industrial salespeople.

Currently both generations are working side-by-side and together account for approximately $68 \%$ of today's workforce (U.S. Census Factfinder Report S2301). Because these two generations entered the workforce with a different set of attitudes, one might expect differences in their subsequent work behavior (Super, Savickas and Super 1996). Some claim these differences are dramatic, distinct and even conflicting (Glass 2007; White 2008). Still others point to commonalities and claim differences are overstated (Deal 2007; Giancola 2006). Both claims tend to be based on largely anecdotal evidence. Thus, one purpose of this study is to offer an empirical argument based on responses gathered from respondents with sales career related work experience. Further, much of the discussion of workplace generational differences does not give specific consideration to the attributes, skills and work environment of the field salesperson. A second contribution, therefore, of this study is to give specific consideration to the independent, autonomous and frequently complex task environment faced by career industrial salespeople. It is under these stressful and demanding work environments that generational differences may emerge. 
The purpose of this study, therefore, is to test these expectations. The subsequent section draws heavily upon generational theories as well as studies of similar occupation groups. The four hypotheses suggested from this section are tested using responses from a cross-section of field salespeople employed with manufacturers. The comparison of these two generational groups carries both meaningful managerial and research implications, which are discussed in the concluding sections.

\section{GENERATIONS AND DISTINGUISHING EVENTS}

The economic and technological climate experienced by Generation X differs dramatically than that of Baby Boomers. Each of these issues (i.e. economic events that differentiate these two generations and technological events that differentiate these two generations) is addressed separately in the subsequent sections. For each set of events psychological employment contract theory suggests the effect of these events should result in either a relational or transactional contract. Thus the hypotheses follow the (1) description of either economic or technological event unique to each generational group and (2) the psychological employment contract theoretically expected outcome. The following sections describe major external events that were experienced by each generation, provide the rationale for the differential effect of these events and ends with a hypothesized direction of these differences.

Since the major thrust of this comparison relates to employment related decisions, the economic conditions facing each generation are described at length. Economic conditions influence the preparation for, selection of and motivation in a salesperson's career. Certainly the tools the salesperson uses have changed dramatically and the degree to which generations diverge regarding the use of technological tools is also examined.

\section{Economic Events}

Currently industrial salespeople, regardless of their age cohort, must now contend with increased competition and industry consolidation. The economic conditions that existed during formative times in each generation's life, however, differed dramatically. Raised during a time of economic expansion, Baby Boomers entered the workforce with high expectations (Wallace 2006). Generation Xers', on the other hand were more likely to witness the effect corporate layoffs and downsizing had on their parents (Baumol, Blinder and Wolff 2003; Kupperschmidt 2000). As a result, Generation Xers tend to be more individualistic, cynical and feel less trusting or secure financially (Smola and Sutton 2002). These differential attitudes are reflected in Rousseau's concept of employee perceived psychological contract (Rousseau 1995). A transactional contract differs from a relational one. Transactional employees do not expect long-term employment with one organization and expend more effort developing transferable marketable skills. Relational employees on the other hand do expect continued employment, feel more loyalty to one organization and expend more effort toward achieving organizational goals.

Because Generation Xers tend to be more individualistic and less secure financially, it is more likely this generation takes a transactional approach to their psychological employment contract. Because Baby Boomers tend to have higher expectations, optimism and likelihood to pursue organizational ideals, it is more likely that this generation's choices will reflect a relational contract. The hypotheses that follow are developed within this conceptual framework (of either relational or transactional psychological contracts) and integrate findings from generational comparisons. The impact of economic conditions on the choices made in preparation for and pursuit of a sales career are subsequently addressed.

Theory and evidence suggest the pattern of sales career paths may not be the same for each generation. Baby Boomers may be more likely to pursue a more traditional career path- one typified by vertical ascension internally up the corporate ladder. In this career path career success was defined as achieving seniority with one firm (over 'job-hopping') and gaining depth of functional experience (i.e. staying in sales related positions rather than moving laterally to non-sales functions) (Reitman and Schneer 2003). Because this traditional career path involves longer tenure with one firm, it would be more consistent with a relational employment contract. Further, comparisons of both global and work-related attitudes indicate Baby Boomers may have a higher proclivity to this path. Specifically, studies have found Baby Boomers are less open to change and place higher importance on values such as stability and conformity (Egri and Ralston 2004; Lyons, Duxbury and Higgins 2005). Baby Boom 
generation expressed higher continuance commitment to profession than Generation Xers and this may imply they are more likely to opt to stay in sales rather than pursue lateral paths (Davis, Pawlowski and Houston 2006).

Generation Xers are more likely to be committed to their own individual and independent career path than loyal to one employer or even one profession (Howe and Strauss 2007; Meda 1996). In a comparison of technical professionals, Finegold, Morhman and Spreitzler (2002) found differences that suggest Generation X is more likely to be committed to their career than to an organization. This level of commitment, according to a comparison of Xer to Baby Boomer accountants may be predicated on congruence (Westerman and Yamamura 2007). When Xer's goal orientation is congruent with the organization's Xer's are more likely to stay. This was not the case for Baby Boomers. Congruence did not predict Baby Boomers' staying or leaving decision. The implication of Westerman and Yammamura's (2007) work therefore is Generation Xers' may be placing more emphasis on their own individual goals. They stay or leave based on the degree to which the organization serves those goals. Given the finding that Xers tend to feel more negatively toward their jobs than Baby Boomers, (Manolis, Levin and Dahlstrom1997) one might expect this generation to act accordingly.

Conceptually, Generation Xers are expected to adopt a transactional psychological contract. As a result Generation X salespeople will move from one firm to another and take positions that build both sales and non-sales skills. Baby Boomers will feel a stronger relationship with their respective employer, pursue tenure with fewer firms and develop a deep set of specialized selling skills. These conceptual relationships are supported by some (but not all) generational comparisons.

Two relevant studies provide partial empirical support for this expectation (i.e. Deal 2007 and Menguc and Bhurian 2004). Longitudinal generational comparisons show early Generation X does tend to change jobs more frequently than their Baby Boomer counterparts. This held true for the age ranges of 20 to 25 as X'ers average job held during this age range was 2.07 as compared to1.11 jobs held during this same age range for their Baby Boomer (BB) counterparts (Deal 2007). This, however, did not hold true for other age categories. The implication of findings of Menguc and Bhurian (2004) comparison of expatriate salespersons' points to a career path for older salespeople that involves more frequent changes in employer - but these changes are not accompanied by higher levels of responsibility. The path for older salespeople in this highly diverse set of sales positions may imply the career path of younger salespeople is one typified by vertical ascension within one firm- and older tend to change employers at lateral or lower positions. (See Appendix A for comparisons of the average number of firms and level of responsibilities for the three age groups in the Menguc and Bhurian 2004 study.)

Because the empirical evidence is mixed, these differences are worth examining again. Conceptually and based on the generational comparisons conducted in non-sales then we might expect Generation Xers to pursue a career path which involves working for more firms and one which involves taking positions in other functional areas (non-sales positions). Baby Boomers may be more likely to take a traditional path, stay in sales and do so with fewer employers.

H1: The career paths of Generation X will differ from that of Baby Boomers.

H1a: Xers are more likely to pursue more circuitous career path: one that is typified by sales and non-sales positions and by more than one firm.

H1b: Baby Boomers are more likely to pursue traditional career paths (one that is typified by holding sales positions within a few firms)

Just as each generation takes a different career path; it is conceivable each generation prepares for a sales career differently. Since transactional employees are more committed to their own career than to one employing organization, it is likely that they will pursue education credentials that have applicability to more than one firm. In an effort to make this type of career investment, the transactional employee may seek more formal levels of education. The relational employee feels more secure in making specific investments such as developing deeper knowledge of company-specific information. In short, the relational employee makes educational investments that are valued to the firm whereas the transactional employee makes educational investments that are valued to the larger marketplace. 
Formal education levels do predict psychological contracts for the research scientist studied by Thompson and Heron (2006). If these findings concerning the impact of a terminal degree (doctorate) are applicable to other levels of formal education, then we may expect different education levels amongst salespeople. This expectation is reasonable given education was an important control variable in explaining the impact of psychological contract on customer service employees behavior (Deery, Walsh and Iverson 2006). Studies have yet, however, to combine the concept of different education levels for different psychological employment contracts with generational comparisons.

We do not have to look too far, however, to see major changes in sales which give rise to higher formal education requirements. First, industrial buyers are more sophisticated, have earned more influence within their organizations and hold more responsible positions. Buyers have become better educated and in an effort to match their demands, sales people in the newer generations are entering the field with more formal education. Second, universities are funding such efforts with 'sales excellence' centers. Professional selling as a viable college curriculum has eclipsed a more vocational image. The number and quality of sales programs is a marked difference between that which Baby Boomers experienced in their college years. For these two practical reasons, we would expect Generation X industrial salespeople would possess a higher level of formal education than their Baby Boomer counterparts.

H2: Gen Xers' education levels will be higher than those of Baby Boomer industrial salespeople.

These generational differences in preparing and choosing a sales career path may also extend to the intrinsic motivation levels. While the conceptual definition of intrinsic motivation includes much more ${ }^{1}$, one item that has been compared across generations measures the degree to which a pers on would volitionally work (rather than work for monetary gain). Two studies imply Baby Boomers may have higher levels of intrinsic motivation (Loo 2001; Smith 2000). Smola \& Sutton (2002), however, compared Gen X to BB on this same item and failed to find meaningful generational differences.

While results using these partial indicators of intrinsic motivation are equivocal, theory would suggest a stronger position. To the degree that Baby Boomers are more likely to perceive their psychological contract with their employer as being relational, higher intrinsic motivation levels would follow (Rousseau 1995). Because organizational support is perceived to be higher under relational contract conditions, the salesperson is more likely to be more involved in their assigned task. During the mid 1970's this organizational support took the form of more empowerment and participative management practices (Meda 1996). This type of management style has been strongly associated with relational contracts -and has an especially powerful effect on customer service levels.

If the Baby Boomer salesperson operates under a relational employment contract, he or she is more likely to provide high service levels required to retain clients, invest effort in developing complex interpersonal skills. In fact sales managers tend to see older salespeople as more committed to serving their clients (Kaplan 2001). When the salesperson takes a high service-orientation and develop the interpersonal skills needed, intrinsic motivation levels tend to be higher (Kanfer and Ackerman 2004).

Generation X salespeople may differ from their Baby Boomer counterparts in that they seek challenge and find intrinsically motivating tasks outside of the employment arena. Repeatedly studies have found generational differences in attitudes toward work-life balance. Generation Xers are not as work centric as their BB counterparts (Smola and Sutton 2002). X'ers place higher value on finding balance between work and family (or non-work endeavors) (Burke 2004). There seems to be a generational shift toward increased emphasis on achieving personal outcomes and away from the self-definitions that are heavily influenced by employer organization affiliations.

This shift may be part of the tendency of Gen Xers to take a transactional rather than relational view of their psychological employment contract. Transactional approach to employment contract places more emphasis on achieving outcomes (and less on developing a deeper more complex skill set). Xers taking this transactional approach will be less intrinsically motivated and develop only the skills needed immediately to achieve short-range goals. This implies a more superficial involvement level and thus a lower level of intrinsic motivation. 
H3: Baby Boomer generation will be more intrinsically motivated than Generation Xers industrial salespeople.

\section{Technological Events}

The pace of technology over the span of both generations has been rapid. The more recent changes in communication and information technology tools unarguably have been the most dramatic. It almost seems a foregone conclusion that the newer generations of salespeople will have shorter learning curves, more comfort level and higher levels of use of these tools. Some evidence suggests, however, this conclusion may not be clear-cut and thus worthy of additional research effort.

Given the strength of these opinions, one would expect academic studies to be confirmatory. This expectation was not upheld as not all studies agree. While four studies found younger tend to use technology more (Harris and Pike 1996; Hunter and Perreault 2006; Rapp, Ahearne and Forbes 2007; Senecal, Pullins and Buehrer 2007) three found no evidence of direct relationship. Specifically, Hunter and Perreault (2007) found experience shared no direct relationship with using technology to access, analyze or communicate. Similarly, Ko and Dennis (2004), Johnson and Whitehorn (1997) and Mathieu, Ahearne and Taylor (2007) failed to find a significant relationship between age (and experience) and technology use.

Baby Boomers tend to see themselves as open to new technology as long as they can see the value in it (Glass 2007). Older salespeople see technology as offering both advantages and presenting complexities (Speier and Venkatesh 2002). It may be that BB may not be as open, but exhibit a healthy skepticism toward (or a more realistic view of) technology. This realism may show itself in the finding that technology use by older salespeople will bring better results than the same use in the hands of younger salespeople (Keillor, Bashaw and Pettijohn 1997).

From the viewpoint of Generation $\mathrm{X}$ and their sales managers, the generational divide is long and wide. Generation $\mathrm{X}$ sees themselves as coming of age with technology and thus this issue is simply part of their 'generational consciousness' (McMullin, Comeau and Jovic 2007). As this generation enters and grows in their sales careers, they continue to see themselves as technologically oriented (Hunter and Perreault 2006). Apparently sales managers share this view and tend to rate Baby Boomers as lacking in technology. Large-scale surveys found managers see Baby Boomers as less technologically sophisticated (Burke 2004). Similarly, a Sales Marketing \& Management survey found 300 sales managers tended to see generational differences on both the use and understanding of technology (Kaplan 2001). Thus the prevailing opinion is that GenXers technology use outweighs that of their Baby Boomer counterparts. Given the mixed evidence -and Baby Boomers' self view, this study will test the prevailing opinion.

H4: Gen Xers' will have higher usage rate of information technology than those of Baby Boomer industrial salespeople.

\section{METHOD}

The sampling frame consisted of salespeople employed by manufacturers in a field sales position. Using this homogeneous sample (i.e. one restricted to geographically dispersed salespeople employed with manufacturers), the comparisons may reflect generational rather than extraneous variability. Surveys were mailed to firms engaged in manufacturing located in the southeastern part of the United States. Responses were returned directly to the university researcher in self-addressed stamped envelopes to assure confidentiality. Surveys were delivered to 981 salespeople and the combination of respondents falling into one of the two generational groups of interest was 132. Therefore the usable response rate for this study (132/981) was $13.45 \%$. Given this response rate, several comparisons were conducted (to gauge the degree to which this sample was representative). Those comparisons included: early to late respondents, participating to non-participating firms in the sampling frame and sampling frame to population.

Since a second request was sent to nonrespondents three weeks following the first early to later respondents were compared (Armstrong and Overton 1977). Early to late respondents were similar in terms of all variables of interest (i.e. membership in generational group, education, gender, career path, intrinsic motivation and technology 
use). These similarities imply the sample may be untainted by response bias.

Given this response rate, it was deemed prudent to compare participant firms to nonparticipant firms. One comparison examined the differences between respondent firms and nonrespondent firms in the same sampling frame (i.e. randomly selected from ABI database). No proportional differences were found (in the number of employees) or in the industry sector. While there were no proportional differences in the total number of employees, firms in this sample tended to employ more salespeople than from nonrespondent firms (Average number of salespeople was 7.92 for the respondents and 4.12 for nonrespondents). This may imply the sample is more biased toward firms that employ larger sales forces. Based on this possible bias another comparison was conducted to test for overall size differences (by comparing the sample profile to yet another database-one from which the sample was not drawn). Since these respondents were generated using American Business Index database, the Lexis-Nexis Dossier database was used as a basis of comparison. No proportional differences were found between the annual revenue of firms employing respondents and those of the population (See Table \#1). This lack of significance may imply respondents in the sample are not systematically different from the population.

Table 1

Comparison Sample (Respondents)

Comparison of Respondents to Non-respondents in Sampling Frame

Number of Employees

20 to 49

50 to 99

100 to 249

250 to 499

500 to 999

Industry Sector

Mfg. Consumer Durable

Mfg Consumer Nondurable

Mfg. Industrial Parts \& Components

Mfg. Supplies

Mfg. Equipment $\underline{\text { Proportion of Non-respondents }}$

$54.16 \%$

$29.17 \%$

$8.33 \%$

0

$8.33 \%$

Chi Square $0.189 \mathrm{df}=4$ probability .9957

Proportion of Non-respondents

$12.5 \%$

$8.3 \%$

$25.0 \%$

$33.3 \%$

$20.8 \%$

Chi Square $0.026085 \mathrm{df}=4$ probability .9988

\begin{tabular}{c} 
Proportion of Respondents \\
\hline $50.0 \%$ \\
$20.8 \%$ \\
$25.0 \%$ \\
$4.2 \%$ \\
0
\end{tabular}

Proportion of Respondents

$17.8 \%$

$11.1 \%$

$22.2 \%$

$25.9 \%$

$22.9 \%$

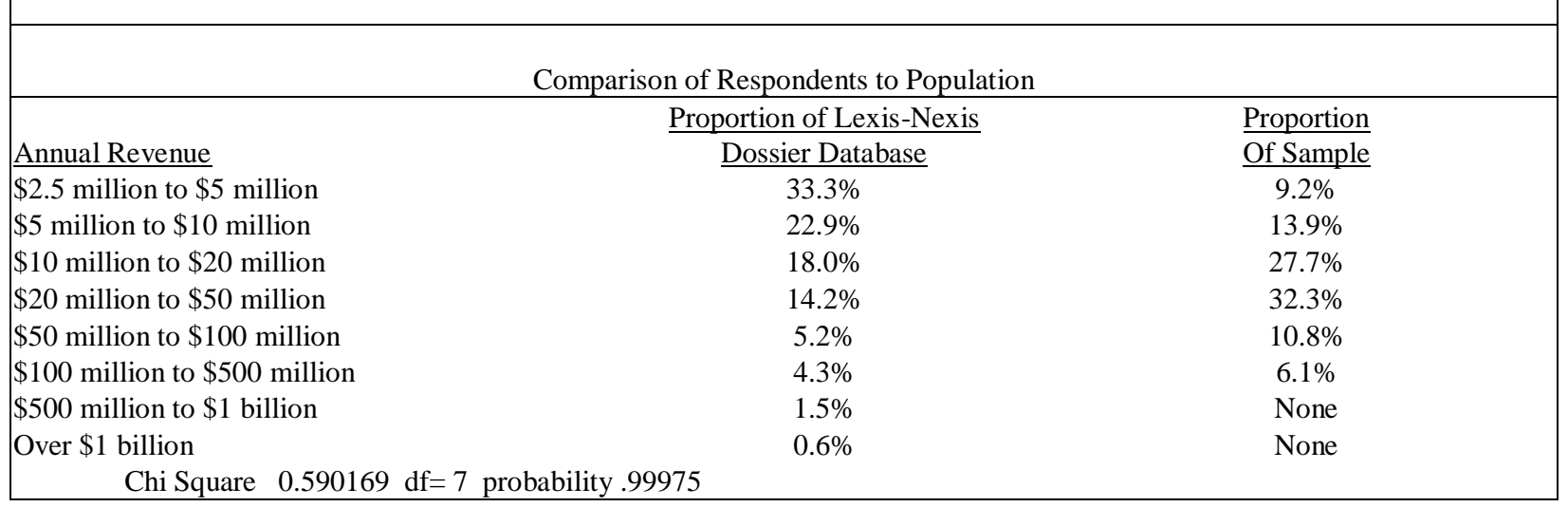




\section{Measures}

The years of birth selected for defining each generation was equivalent in number of birth years spanned and equivalent in the generational sequence of birth years. Thus each generation was defined as those who were born in the first ten years of either the Baby Boom or Generation X age cohort group. Thus a ten-year span of birth years occurring at the early part of the Baby Boom generation (1949 to 1958) to the early part of the Generation Xers (1969 to 1978). This operationalization reduces the opportunity for differences arising from the introduction of respondents born in the cusp with those born in the core years (Egri and Ralston 2004). Using this operationalization in this sample of manufacturer field salespeople 47 respondents were categorized as Generation Xers and 85 as Baby Boomers.

Measures used in this study attempted to find the most objective indicator and reduce the bias inherent in describing a generational group (Kite, Stockdale, Whitley and Johnson 2005; Manolis, Leven and Dahlstrom 1997). Thus all measures here are taken from the respondents falling into one of the two generations -and ask respondents to describe only themselves (not describing another generation).

Career paths were described in terms of four possible paths: two more traditional ones (working with one employer) and two involve changing employers. In both traditional paths the salesperson does not change employers. All of the industry experience gained is with the current firm -and similarly all sales experience is gained through the currently held sales position. This traditional path is labeled 'started and stayed'. The second more traditional path involves taking different positions within that same firm and thus is labeled 'moved through'. Unlike these two traditional career paths, the more circuitous paths involve changing employers within the same industry. The salesperson pursuing this path brings industry experience into the current employer. They may have brought this industry experience into their currently held sales position (and thus are labeled 'came in at current'). Alternatively a salesperson may have brought this industry experience into the current employer at a position other than the currently held sales position (and thus are labeled 'came in at other'). In summary the following list is provided of the four mutually exclusive paths.

Career Path 1: Came in at current position-salesperson entered the currently held sales position with industry experience gained at a different firm.

Career Path 2: Came in at different position-salesperson entered this firm initially in a capacity other than the currently held sales position -and at the time of entry did so with industry experience gained at a different firm.

Career Path 3: Moved Through -salesperson has held other positions within the firm other than the currently held sales position and all of the salesperson's industry-related experience is with the current firm.

Career Path 4: Started and stayed-salesperson has held this sales position within the firm during entire time with the firm and all of the salesperson's industry-related experience is with the current firm.

Intrinsic motivation was measured using the six-item scale from Oliver and Anderson (1994). The standardized coefficient alpha of this scale was .75. Given one of the items makes pointed reference to retirement (i.e. Item \#4 "I wish I did not have to retire someday so I could always continue selling for the pleasure of it."), the possibility this item differed from the other scale items posed a concern. Analysis indicates item 4 did not detract from the internal consistency of this measure (See Table 2). Deletion of item \#4 does not increase the overall coefficient alpha (correlation of Item 4 with total intrinsic score is .65 and the alpha with deletion is .66). Thus the internal reliability level seems to be unrelated to one item referring to retirement. Since the overall coefficient alpha of all six items (i.e. .75) fell within acceptable ranges (Nunnally 1994) and the possibility of an offending item does not seem to exist, the original six items validated scales were deemed an appropriate measure of intrinsic motivation. 
Table 2

Intrinsic Motivation Items Analysis

\begin{tabular}{|c|c|c|c|c|c|c|}
\hline & & $\frac{\text { Correlation }}{\text { with Total }}$ & $\frac{\text { Alpha if }}{\text { deleted }}$ & $\frac{\text { Avg for }}{\underline{\text { Xers }}}$ & $\frac{\mathrm{Avg} \text { for }}{\underline{\mathrm{BB}}}$ & $\begin{array}{l}\underline{\text { Scheffe Diff }} \\
\text { in Averages } \\
\end{array}$ \\
\hline & \multicolumn{6}{|l|}{$\underline{\text { Items }}$} \\
\hline 1 & $\begin{array}{l}\text { Becoming successful in sales is } \\
\text { something that I want to do for me. }\end{array}$ & .23 & .77 & 5.76 & 5.65 & NS \\
\hline 2 & $\begin{array}{l}\text { I do not need a reason to sell; I sell } \\
\text { because I want to. }\end{array}$ & .39 & .74 & 5.98 & 6.18 & NS \\
\hline 3 & $\begin{array}{l}\text { I sell because I cherish the feeling of } \\
\text { performing a useful service. }\end{array}$ & .55 & .70 & 2.65 & 3.71 & $\mathrm{~S}$ \\
\hline 4 & $\begin{array}{l}\text { I wish I did not have to retire someday } \\
\text { so I could always continue selling for } \\
\text { the pleasure of it. }\end{array}$ & .65 & .66 & 3.09 & 3.79 & $\mathrm{~S}$ \\
\hline 5 & $\begin{array}{l}\text { If I were independently wealthy, I } \\
\text { would still sell for the challenge of it. }\end{array}$ & .58 & .69 & 5.30 & 5.38 & NS \\
\hline 6 & $\begin{array}{l}\text { When I perform well I know it is } \\
\text { because of my own desire to achieve. }\end{array}$ & .54 & .71 & 4.89 & 5.21 & NS \\
\hline & Bold indicates larger values & & & & & \\
\hline
\end{tabular}

Use of technology was measured dichotomously for several forms of technology (such as use of hardware such as palm held computing devices, wireless access or software such as CRM or synchronization). Technology questions were framed to ask for this in the context of using each listed technology in the execution or tasks relating to "your current sales position". In addition to measuring current status as either user or nonuser, the survey instrument also asked all respondents (for each form of technology) whether they used this technology previously in the execution of their current sales position responsibilities) but do not do so currently. None of the respondents selected this last option (used previously but not currently). While use of any one of these forms of technology (i.e. palm, wireless, CRM or synchronization software) may indicate more advanced forms of technological sophistication, the combination of these with the more standard laptop computing may be a complementary and additional indicator of technological use. Therefore, technology acceptance was measured as user status of each form as well as the combinatory employment of these more current forms of hardware and software.

\section{RESULTS}

The proportional differences of each generation pursuing one of four career paths were significant. The Chi-Square statistic testing generational differences across career paths was 10.76 (probability of .0131). See Table 3. The pattern of differences, however, was not as expected in the first hypothesis. It was expected that a larger proportion of early Generation X would be changing from one firm to another in sales or non-sales capacities. The respondents in this generational group were aged 25 to 34 and thus had sufficient time to pursue changes. The partial Chi of 3.6088 (probability of .0575) for the proportion of Generation X pursing the career path typified by changing firms (while staying in the same industry and at the currently held sales position) indicates comparatively fewer, rather than more were pursing this career path. While $21.28 \%$ of Generation Xers switched firms (staying within the same industry) at their current sales position, this proportion was much less than that of their Baby Boomer counterparts (48.19\%). Significant differences were found, but those differences ran counter to the direction expected in the first hypothesis. 


\begin{tabular}{|c|c|c|c|}
\hline & $\begin{array}{l}\text { Table } 3 \\
\text { Results }\end{array}$ & & \\
\hline & $\underline{\operatorname{Gen} X}$ & $\frac{\mathrm{BB}}{(\mathrm{n}=84)}$ & \\
\hline \multicolumn{4}{|l|}{ Career Path $\quad \chi^{2} 10.76(p=.0131)$} \\
\hline $\begin{array}{l}\text { Came in at current (had more industry experience } \\
\text { than firm experience - same amount of sales experience } \\
\text { as experience with current firm) }\end{array}$ & $21.28 \% *$ & $48.19 \% *$ & $*$ Partial $\chi^{2} 3.6088_{(\mathrm{p}=.0575)}$ \\
\hline $\begin{array}{l}\text { Came in at other (had more industry experience than } \\
\text { firm experience - but total sales exp not the same as }\end{array}$ & $17.02 \%$ & $6.02 \%$ & \\
\hline Started and stayed & $42.55 \%$ & $31.33 \%$ & \\
\hline Up through ranks & $19.15 \%$ & $14.46 \%$ & \\
\hline \multicolumn{4}{|l|}{ Education $\quad \chi^{2} 13.11_{(\mathrm{p}=.0107)}$} \\
\hline$\overline{\text { High School }}$ & $6.38 \%$ & $19.05 \%$ & \multirow{5}{*}{$*$ Partial $\chi^{2} 4.6794_{(\mathrm{p}=.0305)}$} \\
\hline Some College & $25.53 \%$ & $35.71 \%$ & \\
\hline College Degree & $59.57 \% *$ & $28.57 \% *$ & \\
\hline Some Graduate School & $4.26 \%$ & $7.14 \%$ & \\
\hline Graduate Degree & $4.26 \%$ & $9.52 \%$ & \\
\hline & 27.67 (Avg) & 29.91 (Avg) & \\
\hline$\underline{\text { Intrinsic Motivation }} \mathbf{F}=4.77_{(\mathrm{p}=.0309)}$ & Std.Dev .84 & Std.Dev .64 & \\
\hline \multicolumn{4}{|l|}{ Information Technology Use } \\
\hline Use Palm & $38.64 \%$ & $30.67 \%$ & $\chi^{2} .79_{(\mathrm{p}=.3743)}$ \\
\hline Use WiFi & $16.28 \%$ & $23.94 \%$ & $\chi^{2} .95(\mathrm{p}=.3306)$ \\
\hline Use crm & $22.22 \%$ & $25.64 \%$ & $\chi^{2} \cdot 18(\mathrm{p}=.6706)$ \\
\hline Use Synchronization & $15.91 \%$ & $25.64 \%$ & $\chi^{2} 1.55(\mathrm{p}=.2137)$ \\
\hline $\begin{array}{l}\text { Number of forms of technology } \\
\text { (lap+palm+wifi+crm+synch: } \\
\text { Values } 0 \text { none to all 5) }\end{array}$ & 1.5854 & 1.6176 & $\mathrm{~F}=.01(.9119)$ \\
\hline
\end{tabular}

Generation X has a higher level of formal education than Baby Boomers in this sample. The overall ChiSquare for this comparison was 13.11 with associated probability of .0107 . Moreover, Generation $\mathrm{X}$ has a much higher proportion of college-educated members $(59.57 \%)$ than Baby Boomers $(28.57 \%)$. The partial Chi for this portion of the comparison was 4.6794 (probability of .0305). The second hypothesis was supported as generational differences followed the expected pattern. A larger proportion of Generation X industrial salespeople tend to have higher levels of formal education than their Baby Boomer counterparts.

Since intrinsic motivation was measured using an interval scale, testing the third hypotheses took the form of analysis of variance. As expected Baby Boomers tend to express higher levels of intrinsic motivation as the F-test value was 4.77 with an associated probability of .0309. Scheffe comparison confirmed the finding that Generational X'ers average of 27.67 was lower than Baby Boomers' 29.91 average intrinsic motivation levels. Thus the direction of expected differences in average intrinsic motivation level was confirmed and Baby Boomers tend to feel more intrinsically motivated.

The hypothesized generational differences in technology use, however, were not supported. No meaningful differences were found between these two generational groups in terms of their use of four separate forms of technology (See Table 3). Generation X and Baby Boomers in this sample of manufacturer salespeople do not differ in terms of the proportion using palm devices, wireless connections, CRM software nor synchronization software. 
This comparison of proportions yielded Chi-squares as low as .18 probability of .6706(for CRM) and only as high as 1.55 probability of 2137 (for synchronization software). Testing for the possible combined use of these forms of software (with the more traditional laptop) supported this same pattern. The average number of forms of technology used simultaneously by each generational group is not different ( $\mathrm{F}$ value of .01 ). Generation $\mathrm{X}$ tends to use on average 1.5854 and Baby Boomers 1.6176. The fourth hypothesis, therefore, is not supported and results here indicate no generational differences in technology use exist.

All of the comparisons testing these hypotheses were analyzed separately to test for the existence of firm size as a covariate. The covariate of company size was included in this analysis for two reasons. First, the Generational Differences Survey Report conducted by Society for Human Resource Management found more generational differences are likely to occur in larger firms (Burke 2004). Second, larger companies may have the resources to support technology. By controlling for company size, these analyses may provide a more meaningful comparison of generational differences. In the case of categorical data the impact of the covariate was testing using the Cochran-Mantzel-Hansel test statistic (See Table 4 for probabilities). This analysis indicates the covariate of company size does not change the conclusions for any of the four tested hypotheses.

Table 4

Company Size as Covariate

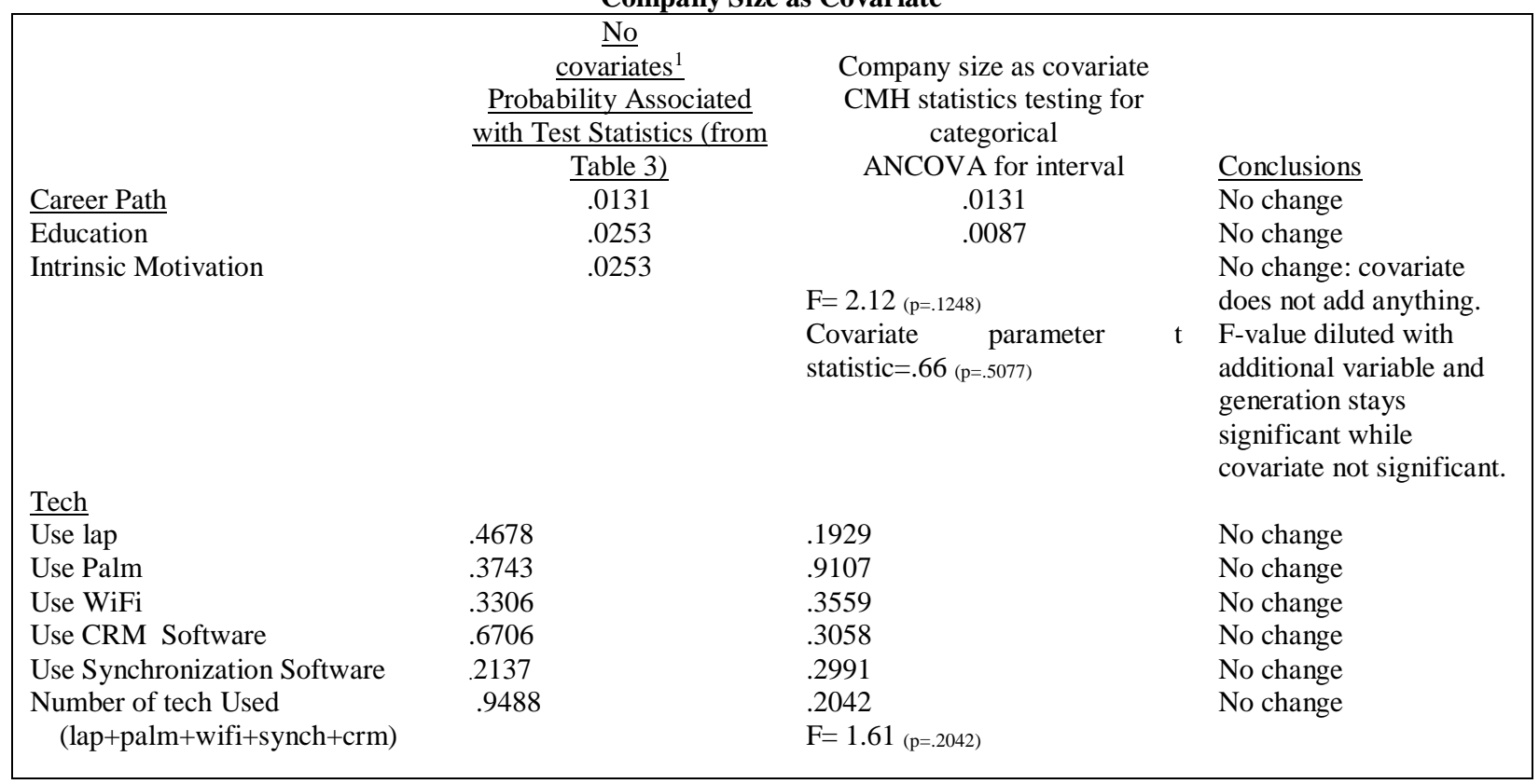

\section{CONCLUSIONS}

Because this study was able to compare two age cohorts who have both had sufficient time to experience the challenges of industrial sales, it fills a gap in generational and sales management topics. Generational literature is replete with early attitudinal surveys as Generation X was emerging-prior to any meaningful career-track work experience. This study provides a closer look at generational differences now that the younger age cohort has had time to understand industrial sales (and not just experiment with this career option). Sales management research, on the other hand, tends to ignore generational differences, believing any age related changes are due to a maturing process reflected in the four career stage models. While certainly far from conclusive, results here suggest, at most, generational differences may exist and, at least, are worthy of more attention.

\footnotetext{
${ }^{1}$ From Table 3
} 
Generational differences were uncovered in career path, intrinsic motivation and formal education. Generation Xers tend to change employers less often than expected and enter the field with a higher level of formal education. Industrial salespeople who are members of the early Baby Boom generation are more intrinsically motivated and surprisingly do not seem to differ from their generational counterparts in technology usage. Overall this comparison indicates some generational differences do exist. The most intriguing findings, however, may lie in that which was not different -and in the pattern of counter-hypothesized differences.

The expectation was that Generation Xers would be taking more circuitous, changeable or malleable career paths. The finding here, however, is that a larger proportion of Baby Boomers are doing so. If as previous literature suggests, Gen Xers are less loyal to organizations and more committed to their own career, they may be building their career in a different pattern than expected. According to these analyses, Generation Xers may be gaining depth of experience and developing skills in a stable environment before venturing out to change employers. Alternatively, the sales positions may be offering Generation Xers the degree of autonomy, freedom from supervision and independence they prefer (Egri and Ralston 2004; Jurkiewicz 2000). When these needs are met, Generation X may not feel the need to change positions.

It was intriguing to find a larger proportion of Baby Boomers moving from one company to another - and doing so at the currently held sales position. This may imply this generation may be leveraging their experience when they change employers. Rather than valuing stability and long tenure, early Baby Boomers in this sample are switching employers within the same industry at a much higher proportion than their Generation X counterparts. Deal (2007) found a similar pattern. In this comparison of Early Boomers to Early Xers at the same two age categories (i.e. ages 31 to 35 and ages 36 to 40). Deal (2007) found Early Boomers held more jobs during both of these age periods. Howe and Strauss (2007) refer to this as a 'generational diagonal' and contend Baby Boomers will not follow the traditional career stage pattern but will replenish, reflect -and keep working. The comparison conducted in this, the study reported here, on a fairly homogeneous sample of manufacturer salespeople may support this notion. Evidence of this study suggests Baby Boomer salespeople are not just continuing to work but are continuing to change employers.

Contrary to expectations and much of the prevailing opinion, these analyses failed to find any generational differences in technology use. While Generation X (and not Baby Boomers) was raised with technology, this does not seem to be reflected in higher on-the-job usage rates. This held true when controlling for the possibility that Generation Xers may be working for larger firms (with more resources to support forms of technology such as Palm Devices, Wireless Connections or CRM). Results here are consistent with SFA studies finding no direct significant relationship with age (Ko and Dennis 2004; Johnson and Whitehorn 1997; Hunter and Perreault 2007; Mathieu, Ahearne and Taylor 2007).

The combination findings concerning career paths, technology and intrinsic motivation lead to yet other possible patterns. Recall, findings here show no differences in technology and Baby Boomers pursuing more circuitous career paths with higher levels of intrinsic motivation. Perhaps this generation of industrial salespeople is adopting technology as they recognize it as a transferable and marketable skill (thus assisting their ability to change employers). Further, evidence from SFA researchers suggests older salespeople are more likely to see the relative advantages will adopt when they see value to the technology (Speier and Venktatesh 2002). When the experienced salesperson does so, they are more productive (Keillor, Bashaw and Pettijohn 1997). To the degree that a Baby Boom salesperson recognizes the promise of productivity, then technology becomes a necessity in today's marketplace.

\section{Managerial Implications}

Overall the pattern of these findings cast the Baby Boom generation in a positive light. Baby Boomers tend to be more intrinsically motivated and career-mobile than their Generation X counterparts. Further the finding that neither generational group uses information technology tools more than the other dispels the image of the older salesperson as a technophile. The profile of Baby Boomers is a positive one and may dispel the image of a disengaged or plateaued salesperson. A Baby Boomer who is seen as plateaued is not likely to use technology at the same rate as his or her younger counterparts. Results here indicate the technology usage rate does not differ- and 
thus the perception of a Baby Boomer as a salesperson resisting the adoption of new tools may not be appropriate. Previous generational research suggests younger managers will be more likely to hold this, a negative image of the Baby Boomer salesperson (Kite, Stockdale, Whitely and Johnson 2005).

Given the tendency for each generation to view the other with bias, managers may need to take caution in applying stereotypes or adopt outmoded images. This study attempted to use objective indicators (such as education level, use or non use status of specific forms of technology and career path descriptors). More subjective indicators (such as one generations view of the other or managers' views of subordinates) tend to be highly biased in this context. Specifically, managers and younger generations tend to believe technology skills of older employees are poorer and less flexible than their younger counterparts (Kaplan 2001; McMullin, Comeau and Jovic 2007). This bias, according to this study and a growing body of SFA literature, may be misplaced and eventually counterproductive. Given the effect of subjective assessments of technological skills, the operationalization of technology use employed objective indicators of use.

Baby Boomer salespeople do tend to express higher levels of intrinsic motivation. The anticipation of higher levels of intrinsic motivation was based on the relational psychological contract concepts. To the degree that the link between higher intrinsic motivation and relational contracts hold true, managers may want to foster the perception - and reality - of developing this type of psychological contract. This advice should be tempered, however, since not all of the relationships derived from the relational psychological contract were supported in this study. For example, if BB are pursuing a relational contract and Xers a transactional one, we should not expect to see a higher proportion of $\mathrm{BB}$ violating long-standing relational contracts and changing employers. This expectation was not upheld and results here indicate a larger proportion of BB salespeople will stay within the industry but change employers (i.e. a larger proportion of BB than Gen Xers). This finding runs counter to the notion that Xers (more so than BB) are more committed to their career than a firm, pursuing a transactional employment contract and open to a more circuitous career path.

Generation $\mathrm{X}$ is the next wave of productive salespeople and findings here indicate managers can require and expect more of this next generation. Generation $X$ is entering the industrial sales field with higher levels of formal education. Recruiting at college level or even requiring a college degree is apparently an acceptable managerial practice. To the degree that a formal education fosters higher levels of analysis or faster skill development, these findings are highly encouraging for sales managers. The newer generation of salespeople may be entering the field with fewer negative sales stereotypes and with more advanced skills sets.

- Sales managers should question their expectations concerning any possible generational differences.

- While the Baby Boomers did not grow up with technology, they are not adverse to using it.

Baby Boomers are engaged in their sales efforts and are still intrinsically motivated.

- Recruiting or retention of sales talent in each generational group may differ.

- Baby Boomer salesperson is open to a flexible career path (changing functions or firms).

- The pool of Generation X salespeople will not be narrowed when managers require higher levels of formal education.

\section{Limitations and Future Research Directions}

The majority of hypotheses were based on the logical link between the economic conditions surrounding each generation and psychological employment contracts (i.e. transactional versus relational). Guided by the thought that $\mathrm{BB}$ would be more relational, higher intrinsic motivation levels were confirmed - but not the pursuit of more traditional career paths. Similarly, it was expected that Xers would be more transactional. To the degree that formal education is seen as a 'less asset specific' and more transferable credential, this transactional view may be true. This formal education level is not as substantial as the finding that Xers do not switch employers as frequently as a transactional salesperson would. The counter-hypothesized results may suggest it would be worthwhile to test the degree to which there is a generational difference in employee perceptions of psychological contracts. This may be an especially rich area of research given the inherently autonomous nature of the field salesperson- and the dramatically changing economic environment into which each generation enters this occupation. 
By restricting the sample to only field salespeople employed with manufacturers and relying predominantly on objective measures, this study was able to reduce extraneous sources of variability and test for generational differences. To some degree this may lend credence to importance of generational distinctions. While this crosssectional design provided for a test of generational differences, it does not address all of the challenges of generational comparisons. The strongest methodology testing for generational differences will demand the most of longitudinal designs. Longitudinal studies tracing both age cohorts and comparing each at the same career stage would provide more and stronger evidence of the impact of generational shifts. This type of analysis could be especially elucidating given the current tendency for the new generation to start their careers later -and for older generations to continue working longer. The trajectory of the typical career stage theory may be changing dramatically in light of these generational shifts.

\section{AUTHOR INFORMATION}

Susan DelVecchio (Ph.D. Virginia Tech) currently serves as an Associate Professor at East Carolina College of Business. Her management experience includes field sales management and corporate strategic marketing with consumer package goods firms. Recently Dr. DelVecchio's research has been published in outlets such as the Journal of Marketing Management and Journal of Business and Industrial Marketing. Research, teaching and consulting areas of specialization include organizing, motivating and training the field sales force.

\section{REFERENCES}

1. Arsenault, Paul M. (2004), "Validating generational differences" Leadership \& Organization Development Journal, 25 (1/2), 124-41.

2. $\quad$ Armstrong, J. Scott and Terry S. Overton (1977), "Estimation nonresponse bias in mail surveys," Journal of Marketing Research, 14 (3), 396-402.

3. Baumol, William J., Alan S. Blinder and Edward N. Wolff (2003), Downsizing in America: Reality, Causes and Consequences, Russell Sage Foundation.

4. Burke, Mary Elizabeth (2004), "Generational differences survey report," Society for Human Resource Managers Research Report, August 2004.

5. Danigelis, Nicholas L., Melissa Hardy and Stephen J. Cutler (2007), "Population aging, intracohort aging and sociopolitical attitudes," American Sociological Review, 72 (October), 812-30.

6. Davis, James B, Suzanne D. Pawlowski and Andrea Houston (2006), "Work commitments of baby boomers and gen-Xers in the IT profession," The Journal of Computer Information Systems, 46 (3), 43-9.

7. Deal, Jennifer J. (2007), "Retiring the Generation Gap: How Employees Young and Old Can find Common Ground," San Francisco, CA: John Wiley \& Sons for Center for Creative Leadership.

8. Deery, Stephen J. Janet T. Walsh and Roderick D. Iverson (2006), "Toward a better understanding of psychological contract breach: a study of customer service employees," Journal of Applied Psychology, 91 (1), 166-75.

9. Egri, Carolyn P and David A. Ralston (2004), "Generational cohorts and personal values: A comparison of China and the United States," Organization Science, 15 (2), 210-20.

10. Finegold, David, Susan Mohrman and Gretchen M. Spreitzler (2002), "Age effects on the predictors of technical workers' commitment and willingness to turnover," Journal of Organizational Behavior, 23 (5), 655-74.

11. Giancola, Frank (2006), “The Generation Gap: More Myth than Reality,” Human Resource Planning, 29 (4), 32-6.

12. Glass, Amy (2007), "Understanding generational differences for competitive success," Industrial and Commercial Training, 39 (2), 98-103.

13. Harris, Kim and John Pike (1996), "Issues concerning adoption and use of sales force automation in the agricultural input supply sector," Agribusiness, 12 (4), 317-26.

14. Howe, Neil and William Strauss (2007), "The next 20 years: how customer and workforce attitudes will evolve," Harvard Business Review, 85 (12), 41-52.

15. Hunter, Gary K. and William D. Perreault, Jr. (2007), "Making sales technology effective, Journal of Marketing, 71 (1), 16-34. 
16. Hunter, Gary K. and William D. Perreault, Jr. (2006), "Sales technology orientation, information effectiveness and sales performance, Journal of Personal Selling and Sales Management, 26 (2), 95-113.

17. Johnson, David, and Whitehorn, Mike (1997), "Justifying the use of portable computer technology by the salesforce of a large insurance company,” The Service Industries Journal, 17 (July), 507-27.

18. Jurkiewicz, Carole L. (2000), "Generation X and the public employee," Public Personnel Management, 29 (1), 55-74.

19. Kaplan, Katharine (2001), "Better with age", Sales and Marketing Management, 153 (7), 58-62.

20. Kanfer, Ruth and Phillip L.Ackerman (2004), "Aging, adult development and work motivation," Academy of Management Review, 29 (3), 440-58.

21. Keillor, Bruce D., R. Edward Bashaw and Charles E. Pettijohn (1997), "Salesforce automation issues prior to implementation: the relationship between attitudes toward technology, experience, and productivity," Journal of Business and Industrial Marketing, 12, (3/4), 209-19.

22. Kite, Mary E. , Gary D. Stockdale, Bernard E.Whitley, Jr. and Blair T. Johnson (2005), "Attitudes toward younger and older adults: an updated meta-analytic review," Journal of Social Issues, 61 (2), 241-66.

23. Ko, Dong-Gil and Alan R. Dennis (2004), "Sales force automation and sales performance: do experience and expertise matter?" Journal of Personal Selling \& Sales Management, 24 (4 Fall), 311-22.

24. Kupperschmidt, B. R. (2000), "Multigenerational employees: strategies for effective management," The Health Care Manager, 19 (1), 65-76.

25. Loo, Robert (2001), "Motivational orientations toward work: an evaluation of the work preference inventory," Measurement and Evaluation in Counseling and Development, 33 (4), 222-33.

26. Lyons, Sean, Linda Duxbury and Christopher Higgins (2005). "Are Gender Differences in Basic Human Values a Generational Phenomenon?” Sex Roles 53 (9-10), 763-774.

27. Mannheim, Karl (1953),"Essays on Sociology And Social Psychology, Oxford University Press.

28. Manolis, Chris, Aron Levin and Robert Dahlstrom (1997), "A generation X scale: creation and validation," Educational and Psychological Measurement, 57 (4), 666-84.

29. Mathieu, John, Michael Ahearne and Scott R.Taylor (2007), "A longitudinal cross-level model of leader and salesperson influences on sales force technology use and performance," Journal of Applied Psychology, 92 (2), 528-37.

30. McMullin, Julie Ann, Tammy Duerden Comeau and Emily Jovic (2007), "Generational affinities and discourses of difference: a case study of highly skilled information technology workers," The British Journal of Sociology, 58 (2), 297-301.

31. Meda, Dominique (1996), "New perspectives on work as value," International Labour Review, 135 (6), 633-51.

32. Menguc, Bulent and Shahid N. Bhurian (2004), "Career stage effects on Job characteristic-job satisfaction relationships among guest worker salespersons," Journal of Personal Selling and Sales Management, 24 (3), 215-27.

33. Mitchell, Susan (1995), “The next baby boom," American Demographics, 17 (10), 22-30.

34. Nunnally, Jum C. (1994) Psychometric Theory, New York City: NY, McGraw-Hill.

35. Oliver, Richard L. and Erin Anderson (1994), "An empirical test of the consequences of behavior- and outcome-based sales control systems," Journal of Marketing, 58 (4), 53-67.

36. Rapp, Adam, Michael Ahearne, and Lukas P. Forbes (2007), "Sales Force Technology Adoption and Performance: The Role of Career Stages," Academy of Marketing Science Summer Conference, Coral Gables, FL. May 24-26, 2007.

37. Reitman, Frieda and Joy A. Schneer (2003), "The promised path: A longitudinal study of managerial careers," Journal of Managerial Psychology, 18 (1), 60-75.

38. Rousseau, Dianne M. (1995), Psychological Contracts In Organizations: Understanding Written and Unwritten Agreements, Thousand Oaks, CA: Sage.

39. Schuman, Howard and Jacqueline Scott (1989), "Generations and collective memories," American Sociological Review, 54 (3), 359-81.

40. Senecal, Sylvain, Ellen Bolman Pullins and Richard E. Bueher (2007), "The extent of technology use and salespeople: an exploratory investigation," Journal of Business \& Industrial Marketing, 22 (1), 52-61.

41. Smith, Tom W. (2000) "Changes in the Generation Gap, 1972-1998," GSS Social Change Report \#43, September, National Science Foundation SBR-9617727. 
42. Smola, Karen Wey and Charlotte D. Sutton (2002) "Generational differences: revisiting generational work values for the new millennium," Journal_of_Organizational Behavior, 23 (2), 363-82.

43. Speier, Cheri and Viswanath Venkatesh (2002), "The hidden minefields in the adoption of sales force automation technologies," Journal of Marketing, 66, (July), 98-111.

44. Super, Donald E., Mark L. Savickas and Charles M. Super (1996), "The life-span, life-space approach to careers," in Career Choice and Development $3^{\text {rd }}$ Edition edited by Duane Brow, Linda Brooks and Associates, San Francisco: Jossey-Bass Inc. pp121-78.

45. Thompson, Marc and Paul Heron (2006), "Relational quality and innovative performance in R\&D based science and technology firms," Human Resource Management Journal, 16 (1), 28-47.

46. U.S. Census Factfinder Report (2006) S2301. Employment Status, 2006 American Community Survey.

47. Wallace, Jean E. (2006), "Work commitment in the legal profession: a study of baby boomers and generation Xers," International Journal of the Legal Profession, 13 (2), 137-51.

48. Westerman, James W. and Jeanne H. Yamamura (2007) "Generational preferences for work environment fit" Career Development International 12 (2), 150-61.

49. White, Erin (2008), "Age Is as Age Does: Making the Generation Gap Work for You," The Wall Street Journal; Eastern Edition, June 30, 2008, B6. 


\section{APPENDIX A}

The following table represents analysis of data provided in Menguc and Bhurian's (2004) study (guest sales workers in Saudi Arabia). The average number of firms worked for by this cross-cultural sample of salespeople increases with age. This increasing pattern, however, was not evident in progressive responsibility level.

(See table below-Menguc and Bhurian (2004) study reported averages and standard deviations but did not test for differences. Tests for differences were conducted by this researcher and reported below. Comparisons were conducted between each of the three age groups for number of firms (self reported by respondents describing the total firms for whom the respondent had ever held employment - in sales capacity or other function). Similarly these three age categories were compared in terms of their current level of sales responsibility (from territory to district and higher). All pairwise t-statistic values were more than 2.00 (all but one probability value was less than $.01)$.

\begin{tabular}{|l|c|c|c|}
\hline \multicolumn{1}{|c|}{ Age } & $\frac{\text { Under 30 }}{\mathrm{n}=151}$ & $\frac{30 \text { to 44 }}{\mathrm{n}=226}$ & $\frac{\text { Over 44 }}{\mathrm{N}=144}$ \\
\hline Number of Firms & 1.67 & 2.32 & 3.28 \\
\hline $\begin{array}{c}\text { Level of responsibility } \\
\text { 1=low level to 4=highest level }\end{array}$ & 3.1 & 2.89 & 2.6 \\
\hline
\end{tabular}

These comparisons imply the number of firms the salespeople work for increase as they age- but each ensuing employer does not necessarily hire the worker at advanced levels of responsibility. 